\title{
Severity of Hypoxemia and Other Factors That Influence the Response to Aerosolized Prostacyclin in ARDS
}

\author{
Richard H Kallet MSc RRT FAARC, Gregory Burns RRT, Hanjing Zhuo MD, Kelly Ho RRT, \\ Justin S Phillips RRT, Lance P Pangilinan RRT, Vivian Yip RRT, Antonio Gomez MD, and \\ Michael S Lipnick MD
}

BACKGROUND: ARDS is characterized by decreased functional residual capacity (FRC), heterogeneous lung injury, and severe hypoxemia. Tidal ventilation is preferentially distributed to ventilated alveoli. Aerosolized prostaglandin $\mathrm{I}_{2}$ exploits this pathophysiology by inducing local vasodilation, thereby increasing ventilation-perfusion matching and reducing hypoxemia. Therefore, aerosolized prostaglandin $\mathrm{I}_{2}$ efficacy may depend upon FRC. Both $\mathrm{P}_{\mathrm{aO}_{2}} / \mathrm{F}_{\mathrm{IO}_{2}}$ and compliance of the respiratory system $\left(\mathrm{C}_{\mathrm{RS}}\right)$ are indirect signifiers of $\mathrm{FRC}$ and thus may partly determine the response to aerosolized prostaglandin $I_{2}$. METHODS: We reviewed the records of 208 ARDS subjects who received aerosolized prostaglandin $I_{2}$ and had arterial blood gases done before and after the initiation of therapy, without other ventilator manipulations. Subjects were grouped according to baseline $\mathrm{P}_{\mathrm{aO}_{2}} / \mathrm{F}_{\mathrm{IO}_{2}}$ (lowest: < 60, intermediate: 60-90, highest: $>90 \mathrm{~mm} \mathrm{Hg}$ ) and $\mathrm{C}_{\mathrm{RS}}(<20,20-29$, $30-39$, and $\geq 40 \mathrm{~mL} / \mathrm{cm}_{2} \mathrm{O}$ ) and by other factors, such as sepsis. Comparisons were analyzed by paired $t$ tests, or Kruskal-Wallis and Dunn post-tests. Multivariate logistic regression modeling was done to determine which of $\mathbf{1 8}$ clinically relevant factors were most predictive for responding to aerosolized prostaglandin $\mathrm{I}_{2}$. $\alpha$ was set at .05 . RESULTS: Mean $\mathrm{P}_{\mathrm{aO}_{2}} / \mathrm{F}_{\mathrm{IO}_{2}}$ increased by $33 \mathrm{~mm} \mathrm{Hg}$ (42\%) upon initiation of prostaglandin $I_{2}$, with a responder rate of $62 \% . \mathrm{P}_{\mathrm{aO}_{2}} / \mathrm{F}_{\mathrm{IO}}$ increased significantly in all oxygenation groups. The highest baseline $\mathrm{P}_{\mathrm{aO}} \mathbf{F}_{2} / \mathrm{F}_{2}$ group had the greatest improvement and responder rate $(51 \pm 63 \mathrm{~mm} \mathrm{Hg}$, and $82 \%)$. In addition, those with sepsis had a smaller improvement in $\mathrm{P}_{\mathrm{aO}_{2}} / \mathrm{F}_{\mathrm{IO}_{2}}$ compared with those without sepsis $(18 \pm 35$ vs $40 \pm 55 \mathrm{~mm} \mathrm{Hg}$, $P=.002)$. Both $\mathrm{P}_{\mathrm{aO}_{2}} / \mathrm{F}_{\mathrm{IO}_{2}}$ and responder rate increased as $\mathrm{C}_{\mathrm{RS}}$ improved, but between-group improvements were not as consistent. In the final model, the only factors that predicted a positive response to aerosolized prostaglandin $\mathrm{I}_{2}$ were baseline $\mathrm{P}_{\mathrm{aO}_{2}} / \mathrm{F}_{\mathrm{IO}}$ (odds ratio 1.10 [1.004-1.205], $P=.042)$ and $C_{\mathrm{RS}}$ (odds ratio 1.04 [1.01-1.08], $P=.02$ ). CONCLUSIONS: Aerosolized prostaglandin $\mathrm{I}_{2}$ improves oxygenation in approximately $60 \%$ of ARDS cases. A favorable response was most strongly associated with baseline $\mathbf{P}_{\mathrm{aO}_{2}} / \mathbf{F}_{\mathrm{IO}_{2}}$ and $\mathbf{C}_{\mathrm{RS}}$. Key words: ARDS; aerosolized prostacyclin; inhaled Flolan. [Respir Care 2017;62(8):1014-1022. ( 2017 Daedalus Enterprises]

\section{Introduction}

ARDS is characterized by severe hypoxemia from altered permeability pulmonary edema leading to decreased functional residual capacity (FRC), which in turn causes hypoxemia from intrapulmonary shunting, and areas of low alveolar ventilation to perfusion. ${ }^{1}$ Pulmonary hyper-

\footnotetext{
Cardiovascular Research Institute, University of California, San Francisco, California.
}

The authors have disclosed no conflicts of interest.

Mr Burns presented a version of this paper as an Editors' Choice abstract at AARC Congress 2016, held October 15-18, 2016, in San Antonio, Texas. 
tension is also a common feature of ARDS resulting from pulmonary vascular endothelial injury as well as from the effects of hypoxemia, hypercapnia, and acidosis that, if sustained, leads to cor pulmonale and increased mortality risk. ${ }^{2}$

\section{See the Related Editorial on Page 1113}

Because lung injury in ARDS is non-homogeneous ${ }^{3}$, portions of the lungs may remain functionally normal, so that tidal ventilation is preferentially distributed to these alveoli. Inhaled vasodilators, such as nitric oxide (NO) ${ }^{4}$ and aerosolized prostaglandin $\mathrm{I}_{2},{ }^{5}$ exploit this pathophysiology by inducing local pulmonary vasodilation, thereby increasing alveolar ventilation/perfusion matching. ${ }^{6}$ These agents also reduce pulmonary arterial pressure in ARDS. ${ }^{7}$ In addition, aerosolized prostaglandin $\mathrm{I}_{2}$ possesses both anti-inflammatory properties ${ }^{8}$ and anticoagulant properties. ${ }^{9}$ In theory, these characteristics may lessen the impact of pulmonary vascular endothelial injury and abnormal pro-coagulation that are prominent features of ARDS. ${ }^{10}$

Because of its heterogeneous nature, the extent and distribution of lung injury in ARDS is relatively unique in individual cases. Therefore, the effectiveness of aerosolized prostaglandin $\mathrm{I}_{2}$ in ARDS may be determined in part by the magnitude of FRC loss. In ARDS, mean FRC is reduced to between 1.8 and $0.6 \mathrm{~L}$ (or approximately 75 to $25 \%$ of normal). ${ }^{11}$ Because FRC is essentially the alveolar volume and the primary determinant of oxygenation and compliance of the respiratory system $\left(\mathrm{C}_{\mathrm{RS}}\right){ }^{12}$ we hypothesized that the initial response to aerosolized prostaglandin $\mathrm{I}_{2}$ in ARDS would be greater in those with less impaired oxygenation. We used both $\mathrm{P}_{\mathrm{aO}} / \mathrm{F}_{\mathrm{IO}_{2}}$ and $\mathrm{C}_{\mathrm{RS}}$ as indirect correlates of FRC status.

In addition, we evaluated whether ARDS etiology (particularly sepsis) or classification as direct versus indirect injury mechanisms modifies the response to aerosolized prostaglandin $\mathrm{I}_{2}$. Inhaled NO and aerosolized prostaglan$\operatorname{din} \mathrm{I}_{2}$ cause vasodilation through similar pathways. ${ }^{13}$ Prior studies reported that inhaled NO was less effective in sepsis-associated ARDS, ${ }^{14,15}$ due to both the blunting effects of endogenous $\mathrm{NO}$ overexpression during sepsis ${ }^{14}$ and sepsis-induced cardiac dysfunction. ${ }^{15}$ Yet others reported that aerosolized prostaglandin $I_{2}$ improved oxygenation only in those with indirect or extrapulmonary etiologies for ARDS (78\% of whom had sepsis). ${ }^{16}$ Therefore, we also investi-

Correspondence: Richard H Kallet MSc RRT FAARC, Respiratory Care Services, Department of Anesthesia and Perioperative Care, Zuckerberg San Francisco General Hospital and Trauma Center, Building 5: GA-2, 1001 Potrero Avenue, San Francisco, CA 94110. E-mail: rich.kallet@ucsf.edu.

DOI: $10.4187 /$ respcare. 05268

\section{QUICK LOOK}

\section{Current knowledge}

Aerosolized prostaglandin $\mathrm{I}_{2}$ has been used to improve oxygenation in subjects with ARDS for $>20 \mathrm{y}$. Most studies have been small and generally have consisted of case series and retrospective reports. Various dosing regimens have been used and have produced modestto-moderate improvements in oxygenation.

\section{What this paper contributes to our knowledge}

The majority of subjects administered aerosolized prostaglandin $\mathrm{I}_{2}$ had an improvement in oxygenation. Both the magnitude of response and the response rate decrease as the degree of oxygenation dysfunction worsens. This suggests that the efficacy of aerosolized prostaglandin $\mathrm{I}_{2}$ is dependent upon the amount of aerated lung. The response to aerosolized prostaglandin $\mathrm{I}_{2}$ was weaker in those with sepsis and stronger in those with trauma-associated ARDS.

gated the response to aerosolized prostaglandin $\mathrm{I}_{2}$ in ARDS subjects with and without evidence of sepsis.

\section{Methods}

We utilized our hospital's ARDS quality assurance database to examine the effectiveness of aerosolized prostaglandin $\mathrm{I}_{2}$ in ARDS. This database registered all patients who met the American-European Consensus Conference definition of acute lung injury from June 2002 to April 2016. ${ }^{17}$ For the purposes of this study, all subjects were reclassified post hoc according to the current Berlin definition of ARDS. ${ }^{18}$ The database was reviewed to identify all patients who received aerosolized prostaglandin $\mathrm{I}_{2}$ during that time period. Approval to use our quality assurance data was granted by our institutional review board. Of the 1,820 patients in the database, 279 had received aerosolized prostaglandin $\mathrm{I}_{2}$. After excluding those who died during the therapy; had intervening increases in PEEP, recruitment maneuvers, or prone positioning; or had missing data/medical record, there were 208 subjects who had an arterial blood gas before and after the initiation of aerosolized prostaglandin $\mathrm{I}_{2}$ and thus were available for analysis (Fig. 1).

Acute Physiology and Chronic Health Evaluation (APACHE II), ${ }^{19}$ Simplified Acute Physiology Score II (SAPS II), ${ }^{20}$ and lung injury scores ${ }^{21}$ were calculated on the day of ARDS onset. Basic demographic information as well as the primary etiology of ARDS and the presence of severe sepsis/septic shock also were collected. Lung injury score was again calculated just before initiating aerosolized prostaglandin $\mathrm{I}_{2}$. In addition, the medical records were 


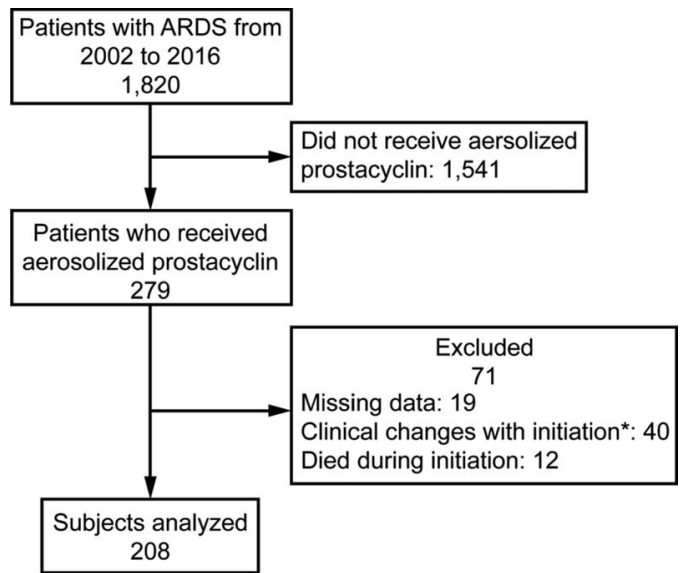

Fig. 1. Flow chart. ${ }^{*}=$ changes in PEEP, prone position, or recruitment maneuvers concurrent with aerosolized prostacyclin initiation.

reviewed to determine all potential mechanisms that might have contributed to the development of ARDS so that lung injury could be classified as being direct, indirect, or mixed. All subjects were managed with one of the ARDSNet ventilator protocols, which is a standard of care at our institution. ${ }^{22,23}$

The aerosol delivery system used was described previously. ${ }^{24}$ In brief, a $50-\mathrm{mL}$ solution of prostacyclin $\left(3.0 \times 10^{4}\right.$ $\mathrm{ng} / \mathrm{mL}$ ) and a $500-\mathrm{mL}$ normal saline solution were infused by a dual-channel volumetric infusion pump into a MiniHEART (Westmed, Tucson, Arizona) jet nebulizer connected to the ventilator circuit with a T-adapter. We found this nebulizer to generate an aerosol with a mass median diameter of $3.12 \pm 0.02 \mu \mathrm{m} .{ }^{24}$ In 2010 , the delivery system was modified using an Aerogen (Mountain View, California.) vibrating mesh technology (mass median diameter of $3.1 \mu \mathrm{m})^{25}$ with a fixed concentration of prostacyclin infused through a single volumetric infusion pump. Therapy commenced at the highest recommended dose (50 $\mathrm{ng} / \mathrm{kg} / \mathrm{min}$ ) and titrated downward. This approach was based on our early experiences with aerosolized prostacyclin indicating that subjects tend to respond quickly to the highest dose. Therefore, our strategy was based on clinical expediency.

Response to aerosolized prostaglandin $\mathrm{I}_{2}$ was assessed primarily by changes in $\mathrm{P}_{\mathrm{OO}_{2}} / \mathrm{F}_{\mathrm{IO}_{2}}$ and also by variables considered to indirectly reflect changes in physiologic dead space: namely the gradient between $\mathrm{P}_{\mathrm{aCO}}$ and end-tidal carbon dioxide tension and corrected minute ventilation $\left(\dot{\mathrm{V}}_{\mathrm{E}} \times \mathrm{P}_{\mathrm{aCO}_{2}} / 40\right) .{ }^{26}$ Data were analyzed according to two categories used as signifiers of FRC impairment. The hypoxemia groups were determined a priori to ensure both reasonably approximate sample sizes and clinically informative cutoffs in baseline $\mathrm{P}_{\mathrm{aO}_{2}} / \mathrm{F}_{\mathrm{IO}_{2}}$ for severe ARDS and were classified as follows: lowest $(<60 \mathrm{~mm} \mathrm{Hg})$, intermediate $(60-90 \mathrm{~mm} \mathrm{Hg})$, and highest $(>90 \mathrm{~mm} \mathrm{Hg})$. The compliance groups were based upon clinically informative cutoffs in $\mathrm{C}_{\mathrm{RS}}:<20 \mathrm{~mL} / \mathrm{cm} \mathrm{H}_{2} \mathrm{O}, 20-29 \mathrm{~mL} / \mathrm{cm} \mathrm{H}_{2} \mathrm{O}$, $30-39 \mathrm{~mL} / \mathrm{cm} \mathrm{H}_{2} \mathrm{O}$, and $\geq 40 \mathrm{~cm} \mathrm{H}_{2} \mathrm{O}$. Marked improvement in oxygenation was defined pre hoc as a $\mathrm{P}_{\mathrm{aO}_{2}} / \mathrm{F}_{\mathrm{IO}_{2}}$ response of $\geq 10 \mathrm{~mm} \mathrm{Hg}$ based on the observations of Walmrath et al. ${ }^{27}$

Statistical analysis was done using either Stata 9.0 (Stata Corp, College Station, Texas) or Instat (GraphPad Software, La Jolla, California). Data are reported as mean \pm SD. Pre-post analysis of variables was done using paired $t$ tests, whereas comparisons between 2 groups (eg, responders and non-responders) were done with unpaired $t$ tests. For non-normally distributed data variables, comparisons were analyzed using either 2-sided Wilcoxon signed-rank tests (pre-post comparisons) or 2-sided Mann-Whitney tests (between-group comparisons). Multiple group comparisons were made using Kruskall-Wallis and Dunn's post-test. Categorical variables were assessed by chi-square tests. $\alpha$ was set at .05 .

Backward, step-wise logistic regression modeling was used to determine which variables differentiated aerosolized prostaglandin $\mathrm{I}_{2}$ responders from non-responders. Variables included in the initial model were age, sex, ethnicity, APACHE II, SAPS II, lung injury score, ARDS etiology, injury category, Berlin definition category, duration of ARDS, presence of sepsis, mean arterial blood pressure, use of vasopressors (both dichotomous classification and number of agents), neuromuscular blockade, baseline $\mathrm{P}_{\mathrm{aO}_{2}} / \mathrm{F}_{\mathrm{IO}_{2}}, \mathrm{C}_{\mathrm{RS}}, \mathrm{V}_{\mathrm{T}}$, PEEP, and nebulizer type. The final model included all variables with a $P \leq .10$.

\section{Results}

\section{General Characteristics}

The majority of our 208 study subjects presented with severe ARDS, as judged by lung injury score at the onset of ARDS and its deterioration at the time that aerosolized prostaglandin $\mathrm{I}_{2}$ was initiated (Table 1). The proportion of subjects classified as having severe ARDS according to the Berlin definition ${ }^{17}$ increased to over four fifths by the time aerosolized prostaglandin $\mathrm{I}_{2}$ was initiated. An equal proportion of subjects could be categorized as direct or indirect injury, whereas a quarter of all subjects had lung injury attributable to both mechanisms. No primary etiology of ARDS was disproportionately represented. Responders also had significantly lower APACHE II, SAPS II, and lung injury scores at ARDS onset (Table 2).

\section{Hemodynamics and the Response to Aerosolized Prostaglandin $\mathbf{I}_{2}$}

Sixty-five percent of all subjects required vasopressors (Table 1). Of these, $36 \%$ required a single agent, $27 \%$ 
Table 1. Demographics, Baseline Characteristics at ARDS Onset, and Outcome

\begin{tabular}{|c|c|}
\hline Variable/Characteristic & Value \\
\hline Age, mean \pm SD y & $48 \pm 18$ \\
\hline Male/female/transgender, $\%$ & $71 / 28 / 1$ \\
\hline \multicolumn{2}{|l|}{ Racial/ethnic characteristics, $\%$} \\
\hline European descent & 38 \\
\hline Hispanic descent & 23 \\
\hline Asian descent & 21 \\
\hline African descent & 15 \\
\hline Middle-eastern descent & 2 \\
\hline Vasopressor use, \% & 65 \\
\hline APACHE* & $26.2 \pm 9.0$ \\
\hline SAPS $*$ & $53.0 \pm 18.6$ \\
\hline LIS* & $3.0 \pm 0.6$ \\
\hline LIS $\dagger$ & $3.3 \pm 0.5^{\neq}$ \\
\hline \multicolumn{2}{|c|}{ ARDS classifications and primary etiologies, $\%$} \\
\hline Severe & $59 * / 83 \dagger$ \\
\hline Moderate & $35^{*} / 16 \dagger$ \\
\hline Mild & $5 * / 1 \dagger$ \\
\hline Direct injury & 34 \\
\hline Indirect injury & 32 \\
\hline Mixed injury & 34 \\
\hline Aspiration & 16.4 \\
\hline Pneumonia & 27.4 \\
\hline Sepsis & 14.9 \\
\hline Trauma & 26.9 \\
\hline Other & $14.4^{\S}$ \\
\hline Hospital mortality, \% & 56 \\
\hline $\begin{array}{l}\text { * Determined at ARDS onset. } \\
\dagger \text { Determined at onset of aerosolized prostacycli } \\
¥ P<.001 \text { compared with lung injury score at } \\
\S \text { Sources included burns/inhalation injuries, her } \\
\text { APACHE = Acute Physiology and Chronic Hea } \\
\text { SAPS = Simplified Acute Physiology Score } \\
\text { LIS = lung injury score }\end{array}$ & and pancreatitis. \\
\hline
\end{tabular}

required a dual agent, 27\% required a triple agent, $7 \%$ required 4 agents, and 2\% required 5 agents. Although the proportion of subjects requiring vasopressors was not different between responders and non-responders, the later required significantly more vasopressor agents (Table 2).

With the exception of higher epinephrine and vasopressin dosages (which reflected 5 subjects who started therapy after aerosolized prostaglandin $\mathrm{I}_{2}$ commenced), vasopressor dosages were not different (Table 3 ). The incidence of hypotension (mean arterial blood pressure $<65 \mathrm{~mm} \mathrm{Hg}$ ) was not different before (29\%) or after initiation (28\%) and had no impact on the magnitude of improvement in $\mathrm{P}_{\mathrm{aO}_{2}} / \mathrm{F}_{\mathrm{IO}_{2}}(29 \pm 44$ vs $34 \pm 52 \mathrm{~mm} \mathrm{Hg}$, respectively; $P \stackrel{59}{=}$. . In the multivariate logistic regression model results, mean arterial blood pressure, vasopressor use, and number of agents used did not determine the responder rate (see below).
Table 2. Characteristics of Responders and non-Responders to Aerosolized Prostaglandin $\mathrm{I}_{2}$

\begin{tabular}{|c|c|c|c|}
\hline Variable & Non-Responders & Responders & $P$ \\
\hline Age, mean \pm SD y & $51 \pm 16$ & $46 \pm 19$ & .065 \\
\hline Female/male/transgender, $\%$ & $35 / 63 / 1$ & $23 / 75 / 2$ & .16 \\
\hline APACHE II & $30 \pm 10$ & $24 \pm 8$ & $<.001$ \\
\hline SAPS II & $60 \pm 19$ & $49 \pm 17$ & $<.001$ \\
\hline Sepsis (co-diagnosis), \% & 38 & 30 & .25 \\
\hline Mortality, \% & 70 & 48 & .002 \\
\hline Vasopressor use, $\%$ & 66 & 64 & .95 \\
\hline $\begin{array}{l}\text { Required number of vasopressors, } \\
\text { mean } \pm \mathrm{SD}\end{array}$ & $2.3 \pm 1.1$ & $1.8 \pm 1.0$ & .007 \\
\hline LIS* & $3.13 \pm 0.52$ & $2.93 \pm 0.54$ & .01 \\
\hline $\operatorname{LIS} \dagger$ & $3.40 \pm 0.38$ & $3.28 \pm 0.48$ & .08 \\
\hline ARDS etiology, \% & & & .059 \\
\hline Aspiration & 18 & 16 & \\
\hline Pneumonia & 29 & 26 & \\
\hline Sepsis & 22 & 11 & \\
\hline Other & 15 & 14 & \\
\hline Trauma & 16 & 33 & \\
\hline Injury category, \% & & & .066 \\
\hline Direct & 33 & 35 & \\
\hline Indirect & 40 & 26 & \\
\hline Mixed & 27 & 39 & \\
\hline $\mathrm{C}_{\mathrm{RS}}$, mean $\pm \mathrm{SD} \mathrm{mL/cm} \mathrm{H}_{2} \mathrm{O}$ & $25 \pm 9$ & $29 \pm 10$ & .01 \\
\hline $\mathrm{P}_{\mathrm{aO}_{2}} / \mathrm{F}_{\mathrm{IO}_{2}}$, mean $\pm \mathrm{SD} \mathrm{mm} \mathrm{Hg}$ & $69 \pm 31$ & $83 \pm 40$ & .008 \\
\hline \multicolumn{4}{|c|}{$\begin{array}{l}\text { * Determined at ARDS onset. } \\
\dagger \text { Determined at onset of aerosolized prostacyclin therapy. } \\
\text { \# Versus indirect injury. } \\
\text { APACHE = Acute Physiology and Chronic Health Evaluation } \\
\text { SAPS = Simplified Acute Physiology Score } \\
\text { LIS = lung injury score } \\
C_{\text {RS }}=\text { compliance of the respiratory system }\end{array}$} \\
\hline
\end{tabular}

Table 3. Vasopressor and Inotropic Dosages Before and After Initiation of Aerosolized Prostaglandin $\mathrm{I}_{2}$ Therapy

\begin{tabular}{lrccc}
\hline \hline \multicolumn{1}{c}{ Treatment } & \multicolumn{1}{c}{$n$} & Pre & Post & $P$ \\
\hline Norepinephrine, $\mu \mathrm{g} / \mathrm{m}$ & 106 & $13.9 \pm 7.0$ & $14.6 \pm 6.9$ & .16 \\
Neosynephrine, $\mu \mathrm{g} / \mathrm{m}$ & 47 & $136 \pm 95$ & $132 \pm 103$ & .73 \\
Epinephrine, $\mu \mathrm{g} / \mathrm{m}$ & 33 & $6.7 \pm 7.2$ & $8.4 \pm 7.7$ & .02 \\
Dopamine, $\mu \mathrm{g} / \mathrm{kg} / \mathrm{m}$ & 27 & $11.0 \pm 8.3$ & $11.2 \pm 6.4$ & .39 \\
Dobutamine, $\mu \mathrm{g} / \mathrm{kg} / \mathrm{m}$ & 3 & $7.33 \pm 6.81$ & $7.33 \pm 6.81$ & .82 \\
Vasopressin, units/m & 68 & $0.037 \pm 0.012$ & $0.040 \pm 0.003$ & .03
\end{tabular}

Results are mean $\pm \mathrm{SD}$

\section{Oxygenation and Ventilation Response to Aerosolized Prostaglandin $I_{2}$}

There were no differences between pre- and post-aerosolized prostaglandin $\mathrm{I}_{2}$ measurements of $\mathrm{F}_{\mathrm{IO}_{2}}$, PEEP, $\mathrm{V}_{\mathrm{T}}$, and mean arterial blood pressure (Table 4). Oxygenation improved markedly after the introduction of aerosolized prostaglandin $\mathrm{I}_{2}$, with mean $\mathrm{P}_{\mathrm{aO}_{2}} / \mathrm{F}_{\mathrm{IO}_{2}}$ increasing by $33 \mathrm{~mm} \mathrm{Hg} \mathrm{(42 \% )} \mathrm{for} \mathrm{the} \mathrm{entire} \mathrm{sample} \mathrm{and} \mathrm{by} 56 \mathrm{~mm} \mathrm{Hg}$ $(80 \%)$ when only responders were considered. A modest 
Table 4. Gas Exchange and Ventilator Variables Before and After Initiation of Aerosolized Prostaglandin $\mathrm{I}_{2}$ Therapy

\begin{tabular}{lccc}
\hline \hline \multicolumn{1}{c}{ Variable } & Pre & Post & $P$ \\
\hline $\mathrm{pH}$ & $7.29 \pm 0.11$ & $7.31 \pm 0.11$ & $<.001$ \\
$\mathrm{P}_{\mathrm{aCO}_{2}}, \mathrm{~mm} \mathrm{Hg}$ & $46 \pm 12$ & $45 \pm 12$ & $<.001$ \\
$\mathrm{P}_{\mathrm{aO}_{2}}, \mathrm{~mm} \mathrm{Hg}$ & $71 \pm 29$ & $101 \pm 59$ & $<.001$ \\
$\mathrm{~F}_{\mathrm{IO}_{2}}$ & $0.94 \pm 0.11$ & $0.95 \pm 0.11$ & .41 \\
$\mathrm{PEEP}, \mathrm{cm} \mathrm{H} \mathrm{H}_{2} \mathrm{O}$ & $14 \pm 4$ & $14 \pm 4$ & .18 \\
$\mathrm{~V}_{\mathrm{T}}, \mathrm{mL}$ & $430 \pm 92$ & $427 \pm 97$ & .46 \\
$\mathrm{~V}_{\mathrm{T}}, \mathrm{mL} / \mathrm{kg}$ & $6.7 \pm 1.2$ & $6.7 \pm 1.2$ & .95 \\
$\mathrm{P}_{\mathrm{aO}} / \mathrm{F}_{\mathrm{IO}}, \mathrm{mm} \mathrm{Hg}$ & $78 \pm 37$ & $110 \pm 67$ & $<.001$ \\
$\dot{\mathrm{V}}_{\mathrm{E}}, \mathrm{L} / \mathrm{m}$ & $12.1 \pm 2.8$ & $12.4 \pm 3.0$ & .003 \\
$\dot{\mathrm{V}}_{\mathrm{Ecorr}_{2}, \mathrm{~L} / \mathrm{m}}$ & $13.9 \pm 4.5$ & $13.8 \pm 4.9$ & .26 \\
$\mathrm{P}_{\mathrm{ETCO}}, \mathrm{mm} \mathrm{Hg}$ & $29 \pm 9$ & $28 \pm 9$ & .006 \\
$\mathrm{P}_{(\mathrm{a}-\mathrm{ET}) \mathrm{CO}_{2}}, \mathrm{~mm} \mathrm{Hg}$ & $17 \pm 10$ & $16 \pm 11$ & .26 \\
$\mathrm{MAP}_{2}, \mathrm{~mm} \mathrm{Hg}$ & $74 \pm 16$ & $74 \pm 16$ & .87
\end{tabular}

Results are mean $\pm \mathrm{SD}$

$\mathrm{V}_{\mathrm{T}}=$ tidal volume

$\dot{\mathrm{V}}_{\mathrm{E}}=$ minute ventilation

$\dot{\mathrm{V}}_{\mathrm{Ecorr}}=$ minute ventilation corrected ("normalized") to a $\mathrm{P}_{\mathrm{aCO}_{2}}$ of $40 \mathrm{~mm} \mathrm{Hg}$,

$\mathrm{P}_{\mathrm{ETCO}_{2}}=$ end-tidal carbon dioxide tension

$\mathrm{P}_{(\mathrm{a}-\mathrm{ET}) \mathrm{CO}_{2}}=$ arterial-to-end tidal carbon dioxide tension gradient

$\mathrm{MAP}=$ mean arterial pressure

reduction was observed in both $\mathrm{P}_{\mathrm{aCO}_{2}}$ and end-tidal carbon dioxide pressure that coincided with a significant, but negligible, increase in $\dot{V}_{\mathrm{E}}$, yet the relative change in $\dot{\mathrm{V}}_{\mathrm{E}}$ (ie, corrected to a $\mathrm{P}_{\mathrm{aCO}_{2}}$ of $40 \mathrm{~mm} \mathrm{Hg}$ ) was not different. The mean time between pre- and post-arterial blood gas measurements was $2.2 \pm 2.0 \mathrm{~h}$. Sixty-seven percent of the pre-/post-arterial blood gas measurements were done within $2 \mathrm{~h}$, and $89 \%$ were done within $4 \mathrm{~h}$.

\section{Impact of Baseline Oxygenation on the Response to Aerosolized Prostaglandin $\mathbf{I}_{2}$}

Those with the least impaired oxygenation (highest group), had a significantly greater improvement in $\mathrm{P}_{\mathrm{aO}_{2}} / \mathrm{F}_{\mathrm{IO}_{2}}$ $(51 \pm 63 \mathrm{~mm} \mathrm{Hg})$ than those in either the intermediate (34 $\pm 46 \mathrm{~mm} \mathrm{Hg}, P=.002$ ) or lowest group (19 $\pm 37 \mathrm{~mm} \mathrm{Hg}, P<.001)$ (Fig. 2). When only responders were considered, the increase in $\mathrm{P}_{\mathrm{aO}_{2}} / \mathrm{F}_{\mathrm{IO}_{2}}$ was $70 \pm 49$ (highest group), $58 \pm 46$, (intermediate group) and $39 \pm 45$ for (lowest group). Among responders, when compared with the lowest group, the magnitude of increase in $\mathrm{P}_{\mathrm{aO}_{2}} / \mathrm{F}_{\mathrm{IO}_{2}}$ was significantly greater in both the intermediate $(P=.039)$ and highest groups $(P=.005)$.

\section{Impact of Baseline $\mathbf{C}_{\mathbf{R S}}$ on the Response to Aerosolized Prostaglandin $\mathbf{I}_{2}$}

All four $\mathrm{C}_{\mathrm{RS}}$ groups also had a significant improvement $(P<.001)$ in oxygenation with aerosolized prostaglandin $\mathrm{I}_{2}$ (Fig. 3). Unlike the oxygenation groups, however, there was

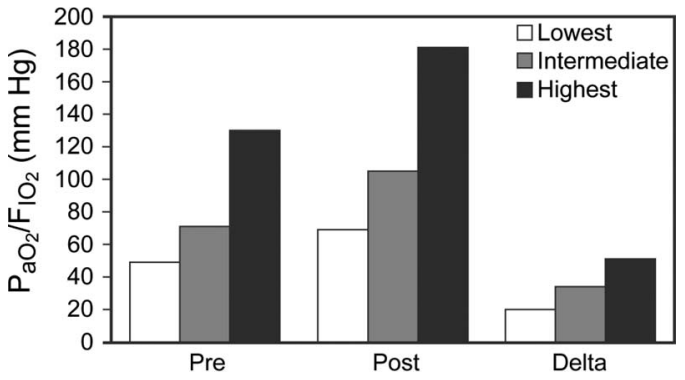

Fig. 2. Mean ratio of $\mathrm{P}_{\mathrm{aO}_{2}} / \mathrm{F}_{\mathrm{IO}_{2}}$ before and after the initiation of aerosolized prostacyclin and the magnitude of change based on the severity of oxygenation defects in Group $\mathrm{A}\left(\mathrm{P}_{\mathrm{aO}_{2}} / \mathrm{F}_{\mathrm{IO}_{2}}<\right.$ $60 \mathrm{~mm} \mathrm{Hg})$, Group B $\left(\mathrm{P}_{\mathrm{aO}_{2}} / \mathrm{F}_{\mathrm{IO}_{2}} 60-90 \mathrm{~mm} \mathrm{Hg}\right)$, and Group $\mathrm{C}$ $\left(\mathrm{P}_{\mathrm{aO}_{2}} / \mathrm{F}_{\mathrm{IO}_{2}}>90 \mathrm{~mm} \mathrm{Hg}\right)$.

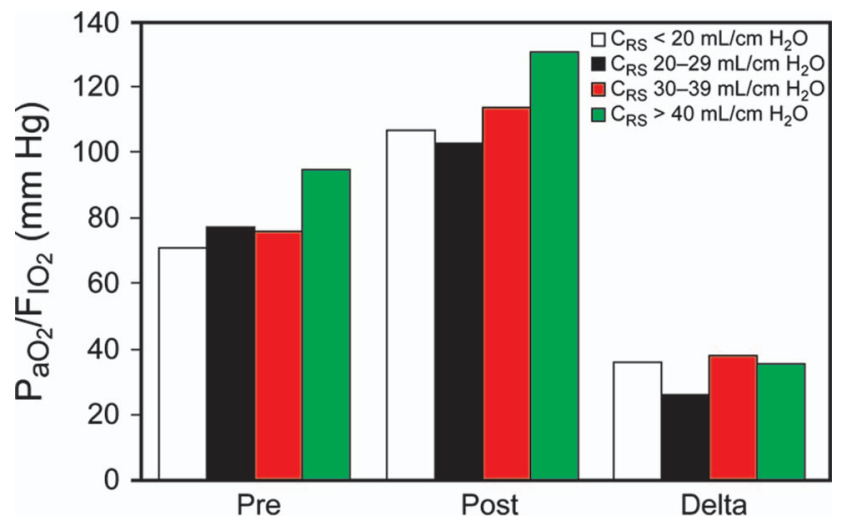

Fig. 3. Mean $\mathrm{P}_{\mathrm{aO}_{2}} / \mathrm{F}_{1 \mathrm{O}_{2}}$ before and after the initiation of aerosolized prostacyclin and the magnitude of change based on groupings according to derangements in compliance of the respiratory system $\left(C_{\mathrm{RS}}\right)$.

not a steadily increasing improvement in the magnitude of $\mathrm{P}_{\mathrm{aO}} / \mathrm{F}_{\mathrm{IO}_{2}}$ response, since $\mathrm{C}_{\mathrm{RS}}$ increased whether all subjects $(P=.27)$ or only responders $(P=.58)$ were considered. This was readily apparent when comparing the columns marked "Delta" between Figure 2 and Figure 3. Nonetheless, the number of aerosolized prostaglandin $\mathrm{I}_{2}$ responders tended to increase as $\mathrm{C}_{\mathrm{RS}}$ improved: $53 \%\left(\mathrm{C}_{\mathrm{RS}}<20 \mathrm{~mL} / \mathrm{cm} \mathrm{H}_{2} \mathrm{O}\right)$, $56 \%\left(\mathrm{C}_{\mathrm{RS}}=20-29 \mathrm{~mL} / \mathrm{cm} \mathrm{H}_{2} \mathrm{O}\right), 75 \%\left(\mathrm{C}_{\mathrm{RS}}=30-39\right.$ $\left.\mathrm{mL} / \mathrm{cm} \mathrm{H}_{2} \mathrm{O}\right)$, and $68 \%\left(\mathrm{C}_{\mathrm{RS}} \geq 40 \mathrm{~mL} / \mathrm{cm} \mathrm{H}_{2} \mathrm{O}\right)$. Among responders, there was an impressive increase in $\mathrm{P}_{\mathrm{aO}_{2}} / \mathrm{F}_{\mathrm{IO}_{2}}$ : $67 \pm 64\left(\mathrm{C}_{\mathrm{RS}}<20 \mathrm{~mL} / \mathrm{cm} \mathrm{H}_{2} \mathrm{O}\right), 49 \pm 37,\left(\mathrm{C}_{\mathrm{RS}}=20-\right.$ $\left.29 \mathrm{~mL} / \mathrm{cm} \mathrm{H}_{2} \mathrm{O}\right), 53 \pm 49\left(\mathrm{C}_{\mathrm{RS}}=30-39 \mathrm{~mL} / \mathrm{cm} \mathrm{H}_{2} \mathrm{O}\right)$, and $62 \pm 49 \mathrm{~mm} \mathrm{Hg}\left(\mathrm{C}_{\mathrm{RS}} \geq 40 \mathrm{~mL} / \mathrm{cm} \mathrm{H}_{2} \mathrm{O}\right)$. Significant differences were observed between $\mathrm{C}_{\mathrm{RS}}$ groups: $\mathrm{C}_{\mathrm{RS}}<20$ versus $\mathrm{C}_{\mathrm{RS}}=30-39 \mathrm{~mL} / \mathrm{cm} \mathrm{H} \mathrm{H}_{2} \mathrm{O}(P=.009) ; \mathrm{C}_{\mathrm{RS}}=20-29$ versus $\mathrm{C}_{\mathrm{RS}}=30-39 \mathrm{~mL} / \mathrm{cm} \mathrm{H}_{2} \mathrm{O}(P=.02)$.

\section{ARDS Etiology and the Response to Aerosolized Prostaglandin $\mathbf{I}_{2}$}

Regardless of ARDS etiology, $\mathrm{P}_{\mathrm{aO}_{2}} / \mathrm{F}_{\mathrm{IO}_{2}}$ increased significantly in response to aerosolized prostaglandin $\mathrm{I}_{2}$ (Ta- 
Table 5. Oxygenation Response to Aerosolized Prostaglandin $\mathrm{I}_{2}$ Based on Etiology of ARDS

\begin{tabular}{|c|c|c|c|c|c|}
\hline Etiology & $n$ & $\mathrm{P}_{\mathrm{aO}_{2}} / \mathrm{F}_{\mathrm{IO}_{2}}$ (pre) & $\mathrm{P}_{\mathrm{aO}_{2}} / \mathrm{F}_{\mathrm{IO}_{2}}$ (post) & $\Delta \mathrm{P}_{\mathrm{aO}_{2}} / \mathrm{F}_{\mathrm{IO}_{2}}$ & Responders \\
\hline Trauma & 57 & $86 \pm 44$ & $135 \pm 77 *$ & $49 \pm 54$ & $77 \%$ \\
\hline Aspiration & 33 & $70 \pm 30$ & $109 \pm 60 \dagger$ & $39 \pm 58$ & $60 \%$ \\
\hline Other & 29 & $71 \pm 38$ & $108 \pm 82 *$ & $37 \pm 15$ & $59 \%$ \\
\hline Pneumonia & 57 & $78 \pm 33$ & $102 \pm 55^{*}$ & $24 \pm 39 \ddagger$ & $56 \%$ \\
\hline Sepsis & 32 & $77 \pm 38$ & $87 \pm 47 \S$ & $10 \pm 39 \|$ & $50 \%$ \\
\hline \multicolumn{6}{|c|}{$\begin{array}{l}\text { Results are mean } \pm \mathrm{SD} \text {. } \\
* P<.001 \text { compared with } \mathrm{P}_{\mathrm{aO}_{2}} / \mathrm{F}_{\mathrm{IO}_{2}} \text { (pre). } \\
\dagger P=.002 \text { compared with } \mathrm{P}_{\mathrm{aO}_{2}} / \mathrm{F}_{\mathrm{F}_{2}} \text { (pre). } \\
\S P=.008 \text { compared with } \mathrm{P}_{\mathrm{aO}_{2}} / \mathrm{F}_{\mathrm{IO}_{2}} \text { (pre). } \\
¥ P=.006 \text { compared with the trauma cohort. } \\
\| P=.001 \text { compared with the trauma cohort. }\end{array}$} \\
\hline
\end{tabular}

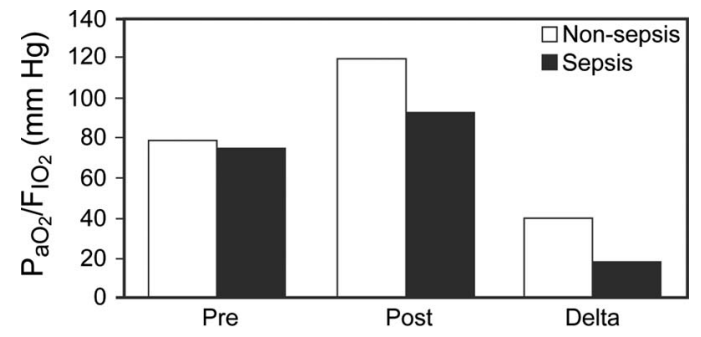

Fig. 4. Mean $\mathrm{P}_{\mathrm{aO}_{2}} / \mathrm{F}_{1 \mathrm{O}_{2}}$ before and after the initiation of aerosolized prostacyclin and the magnitude of change based on the presence or absence of sepsis.

ble 5). Subjects with trauma-associated ARDS had the largest increase in $\mathrm{P}_{\mathrm{aO}} / \mathrm{F}_{\mathrm{IO}_{2}}$, which was significantly greater compared with those with ARDS associated with either pneumonia or sepsis. Although the baseline $\mathrm{P}_{\mathrm{aO}} / \mathrm{F}_{\mathrm{IO}_{2}}$ also was higher in subjects with trauma-associated ARDS, the differences between etiologies in baseline $\mathrm{P}_{\mathrm{aO}_{2}} / \mathrm{F}_{\mathrm{IO}_{2}}$ was not significant $(P=.28)$.

Subjects with sepsis as the primary source of ARDS had both the smallest increase in $\mathrm{P}_{\mathrm{aO}_{2}} / \mathrm{F}_{\mathrm{IO}_{2}}$ and lowest responder rate. All subjects who had sepsis as a contributing factor in the development of ARDS $(n=68)$ were compared with those without sepsis $(n=139)$. Despite having a similar baseline oxygenation, those with sepsis had a significantly smaller improvement in $\mathrm{P}_{\mathrm{aO}} / \mathrm{F}_{\mathrm{IO}_{2}}$ in response to aerosolized prostaglandin $\mathrm{I}_{2}$ than those without sepsis $(18 \pm 35$ vs $40 \pm 55, P=.02$ ) (Fig. 4). Subjects with sepsis as a primary or secondary source of ARDS also tended to have a lower responder rate compared with those without sepsis (55\% vs $65 \%$ ), although this was not significant (odds ratio 0.78 [95\% CI $0.55-1.11$ ], $P=.23$ ).

Direct and indirect sources of ARDS each accounted for $37 \%$ of the sample, whereas mixed mechanisms accounted for $26 \%$. Regardless of etiology, all groups experienced significant increases in $\mathrm{P}_{\mathrm{aO}_{2}} / \mathrm{F}_{\mathrm{IO}}$ in response to aerosolized prostaglandin $\mathrm{I}_{2}(P<.001)$. The magnitude of improvement in $\mathrm{P}_{\mathrm{O}_{2}} / \mathrm{F}_{\mathrm{IO}_{2}}$ for direct, indirect, and mixed was $34 \pm 51$, $22 \pm 45$, and $41 \pm 51 \mathrm{~mm} \mathrm{Hg}$, respectively, and was significant only between indirect and mixed mechanisms $(P=.03)$. In addition, the respective responder rate was 64,55 , and $67 \%$ and was not statistically significant.

\section{Impact of ARDS Duration Before Commencing Aerosolized Prostaglandin $\mathbf{I}_{2}$}

In the majority of subjects (55\%), aerosolized prostaglandin $\mathrm{I}_{2}$ was initiated on the day of ARDS onset, and $82 \%$ of initiations occurred in the early phase of ARDS (ie, days 1-4). Initiation during either the early or later phases of ARDS was associated with significant improvements in $\mathrm{P}_{\mathrm{aO}_{2}} / \mathrm{F}_{\mathrm{IO}_{2}}(77 \pm 37$ vs $111 \pm 69 \mathrm{~mm} \mathrm{Hg}, P<.001$; $82 \pm 39$ vs $109 \pm 57 \mathrm{~mm} \mathrm{Hg}, P<.001$, respectively). Also, the magnitude of $\mathrm{P}_{\mathrm{aO}_{2}} / \mathrm{F}_{\mathrm{IO}_{2}}$ improvement was not different between ARDS phases $(34 \pm 53 \mathrm{~mm} \mathrm{Hg}$ vs $27 \pm 29 \mathrm{~mm} \mathrm{Hg}$, respectively, $P=.96$ ).

\section{Multivariate Regression Model}

Most variables of interest included in the initial model failed to predict aerosolized prostaglandin $\mathrm{I}_{2}$ responders. Of particular interest, factors such as nebulizer type (miniHeart vs Aerogen), baseline PEEP, $\mathrm{V}_{\mathrm{T}}$, ARDS etiology, injury mechanism (ie, direct, indirect, mixed), sepsis, mean arterial blood pressure, and vasopressor use fell out of the initial model. In the final model, aerosolized prostaglandin $\mathrm{I}_{2}$ responders were associated with baseline $\mathrm{P}_{\mathrm{aO}_{2}} / \mathrm{F}_{\mathrm{IO}_{2}}, \mathrm{C}_{\mathrm{RS}}$, lower APACHE II score, and absence of neuromuscular blockade (Table 6). For every $10 \mathrm{~mm} \mathrm{Hg}$ increase in baseline $\mathrm{P}_{\mathrm{aO}} / \mathrm{F}_{\mathrm{IO}_{2}}$, the odds of responding to aerosolized prostaglandin $\mathrm{I}_{2}$ increased by $10 \%$, whereas for every $1-\mathrm{mL} / \mathrm{cm}$ $\mathrm{H}_{2} \mathrm{O}$ increase in baseline $\mathrm{C}_{\mathrm{RS}}$, the odds of responding increased by $4 \%$. For every 1-point increase in APACHE II measured at ARDS onset, the odds of responding to aerosolized prostaglandin $\mathrm{I}_{2}$ diminished by $7 \%$. Although only approaching statistical significance, the absence of neuromuscular blockade also decreased the odds of responding by $42 \%$. 
Table 6. Adjusted Analysis of Aerosolized Prostaglandin $\mathrm{I}_{2}$ Response as a Function of Baseline $\mathrm{P}_{\mathrm{aO}_{2}} / \mathrm{F}_{\mathrm{IO}_{2}}$ and Compliance of the Respiratory System

\begin{tabular}{lccc}
\hline \hline \multicolumn{1}{c}{ Variable } & Odds Ratio & $95 \% \mathrm{CI}$ & $P$ \\
\hline $\mathrm{P}_{\mathrm{aO}} / \mathrm{F}_{\mathrm{IO}_{2}}$ & $1.10^{*}$ & $1.004-1.205$ & .042 \\
$\mathrm{C}_{\mathrm{RS}}$ & $1.04 \dagger$ & $1.01-1.08$ & .02 \\
$\mathrm{APACHE} \mathrm{II}$ & $0.93 \ddagger$ & $0.90-0.97$ & $<.001$ \\
$\mathrm{NMB}$ & $0.58 \S$ & $0.31-1.08$ & .09
\end{tabular}

* Per 10-mm Hg change in baseline value.

$\dagger$ Per 1-mL/cm $\mathrm{H}_{2} \mathrm{O}$ change in baseline value.

\$ Per 1-unit change in score.

$\$$ Signifies the impact of an absence of neuromuscular blockade therapy.

$\mathrm{C}_{\mathrm{RS}}=$ compliance of the respiratory system

APACHE $=$ Acute Physiology and Chronic Health Evaluation

$\mathrm{NMB}=$ neuromuscular blockade

\section{Discussion}

Inhaled pulmonary vasodilators commonly are used for treating refractory hypoxemia despite limited data indicating precisely which ARDS patients may benefit. In the present study, approximately $60 \%$ of subjects had significantly improved oxygenation with aerosolized prostaglandin $\mathrm{I}_{2}$. Moreover, we demonstrated that 2 of the classic signifiers of FRC in ARDS, baseline oxygenation (as measured by $\mathrm{P}_{\mathrm{aO}_{2}} / \mathrm{F}_{\mathrm{IO}_{2}}$ ) and $\mathrm{C}_{\mathrm{RS}}$, are the most salient determinants of a positive response to aerosolized prostaglandin $\mathrm{I}_{2}$. The magnitude of improvement in $\mathrm{P}_{\mathrm{aO}_{2}} / \mathrm{F}_{\mathrm{IO}_{2}}$ in our ARDS subjects was greater than that found in some studies of ARDS $\left(\Delta \mathrm{P}_{\mathrm{aO}_{2}} / \mathrm{F}_{\mathrm{IO}_{2}}\right.$ of $\left.10-21 \mathrm{~mm} \mathrm{Hg}\right),{ }^{7,16,24,27-29}$ but was consistent with others $(28-44 \mathrm{~mm} \mathrm{Hg}){ }^{6,30-32}$ In addition, those with least impaired oxygenation had a significantly greater improvement in $\mathrm{P}_{\mathrm{OO}_{2}} / \mathrm{F}_{\mathrm{IO}_{2}}$ and a substantially higher responder rate than those with more severely impaired baseline oxygenation. Although the $\mathrm{C}_{\mathrm{RS}}$ groups did not demonstrate the same pattern of a proportional increase in the magnitude of oxygenation improvement, nonetheless there was a distinct increase in the response rate to aerosolized prostaglandin $\mathrm{I}_{2}$ as $\mathrm{C}_{\mathrm{RS}}$ improved.

Our findings support the study hypothesis that the effectiveness of aerosolized prostaglandin $I_{2}$ is dependent upon the amount of aerated lung parenchyma, signified by FRC. They are also in accord with the classic studies on lung mechanics and gas exchange in ARDS demonstrating that oxygenation efficiency and $\mathrm{C}_{\mathrm{RS}}$ are directly related to FRC. ${ }^{33,34}$ From this, it follows that the effectiveness of aerosolized prostaglandin $\mathrm{I}_{2}$ might be enhanced when combined with lung recruitment strategies, such as higher PEEP, prone positioning, and/or recruitment maneuvers. A review of prone positioning cited several studies where combining inhaled NO with prone position had an additive effect on improving oxygenation. ${ }^{35}$ Therefore, when initiation of aerosolized prostaglandin $\mathrm{I}_{2}$ therapy fails to im- prove oxygenation sufficiently, clinicians might consider additional therapies (eg, prone position, higher PEEP, or recruitment maneuvers) that may enhance the effects of either aerosolized prostaglandin $\mathrm{I}_{2}$ or inhaled $\mathrm{NO}$ in very severe cases of ARDS.

Our subjects with sepsis had smaller improvement in $\mathrm{P}_{\mathrm{aO}_{2}} / \mathrm{F}_{\mathrm{IO}_{2}}$ and a tendency toward a lower response rate to aerosolized prostaglandin $\mathrm{I}_{2}$. Sepsis causes endothelial dysfunction, leading to deregulated release of both nitric oxide and prostacyclin. ${ }^{36}$ Therefore, our results are consistent with other studies that found that inhaled NO is less effective in improving gas exchange in sepsis-associated ARDS. ${ }^{14,15}$ This appears to be a novel finding, since we are unaware of any aerosolized prostaglandin $\mathrm{I}_{2}$ study reporting diminished response in sepsis-associated ARDS. In contrast, subjects with trauma-associated ARDS tended to have both a greater improvement in $\mathrm{P}_{\mathrm{aO}_{2}} / \mathrm{F}_{\mathrm{IO}_{2}}$ and response rate. This also appears to be a novel finding, though it shares similarities with other studies. Trauma-associated ARDS is distinct from other etiologies in terms of often having both a less severe clinical course and lower systemic inflammatory response ${ }^{37}$ as well as lower dead-space ventilation $^{38}$ and lower mortality. ${ }^{39,40}$

Both the magnitude of improvement and response rate of $\mathrm{P}_{\mathrm{aO}} / \mathrm{F}_{\mathrm{IO}_{2}}$ to aerosolized prostaglandin $\mathrm{I}_{2}$ were not different when subjects were classified as having either direct or indirect injury. This is in contrast to the findings of Domenighetti et al, ${ }^{16}$ who found that aerosolized prostaglandin $\mathrm{I}_{2}$ was only effective in those with indirect injury. However, only 14 subjects were studied. Given our findings that approximately $40 \%$ of subjects with ARDS are non-responders, this may only reflect an artifact from a small sample size.

A meta-analysis ${ }^{41}$ of aerosolized prostaglandin $I_{2}$ in ARDS concluded that there was insufficient evidence supporting the routine use of aerosolized prostaglandin $\mathrm{I}_{2}$, because there is no indication that it improves outcomes despite improving oxygenation. However, complex phenomena, such as determinants of mortality in ARDS, are not necessarily amenable to a single therapy. Aerosolized prostaglandin $I_{2}$ might be useful in concert with other therapies targeting a specific goal known to impact mortality. In the absence of demonstrable harm or excessive cost/benefit ratio, there is a justifiable rationale to pursue using inhaled vasodilators in subsets of ARDS described below.

There is persuasive evidence that cor pulmonale is associated with mortality in ARDS and is present in approximately $50 \%$ of severe cases. ${ }^{42-44}$ Also, preclinical research has demonstrated the additive effects of high-stretch tidal ventilation and hyperoxia in promoting ventilator-induced lung injury. ${ }^{45}$ Given the heterogeneous nature of lung injury and maldistribution of $\mathrm{V}_{\mathrm{T}}$ despite achieving lungprotective goals, ${ }^{46}$ it remains plausible that prolonged, regional exposure to both excessive stretch and hyperoxia 


\section{Aerosolized Prostacyclin Response in ARDS}

may impact outcomes in ways not yet appreciated. The ability of aerosolized prostaglandin $\mathrm{I}_{2}$ to improve oxygenation and reduce right-ventricular afterload at a less toxic $\mathrm{F}_{\mathrm{IO}_{2}}$ might yet be shown to improve outcomes when incorporated into a multitargeted approach. In the interim, we would suggest that aerosolized prostaglandin $\mathrm{I}_{2}$ be considered in these situations, particularly when right-heart dysfunction is suspected or demonstrated by echocardiography.

The majority of our subjects $(68 \%)$ were studied within $48 \mathrm{~h}$ of ARDS onset, with $83 \%$ of all subjects meeting severe ARDS criteria at the time aerosolized prostaglandin $\mathrm{I}_{2}$ therapy commenced. However, our mortality was higher than the ranges reported both by the Berlin Definition Study Group ${ }^{18}$ and the more recent LUNG SAFE Investigators $^{47}$ (56\% vs $42-48 \%$ and $42-50 \%$, respectively). Direct comparisons between our cohort and these studies are problematic because the latter were based on classifications determined on the day of ARDS onset. Moreover, our subjects were a distinct subset of severe ARDS that could be classified as non-responders to traditional therapy, hence the need for ancillary strategies traditionally considered to be salvage or rescue therapies.

The limitations of our study stem from its retrospective nature and its being based upon a single center. However, our study is by far the largest ever done on aerosolized prostaglandin $\mathrm{I}_{2}$ in ARDS with diverse, well-represented etiologies, as well as having subjects of diverse racial/ethnic backgrounds. It also was done predominantly in highly unstable subjects early in the course of severe ARDS. These represent the cohort of ARDS patients most in need of effective therapies to stabilize gas exchange and in whom evidence suggests that other therapies (higher PEEP, ${ }^{48}$ prone positioning, ${ }^{49}$ recruitment maneuvers, ${ }^{50}$ and neuromuscular blockade ${ }^{51}$ ) improve outcomes. Our results, therefore, provide uniquely detailed information that might inform the design of a future trial to assess whether aerosolized prostaglandin $\mathrm{I}_{2}$ might improve outcomes in a highly circumspect subset of ARDS.

\section{Conclusions}

In summary, aerosolized prostaglandin $\mathrm{I}_{2}$ improved oxygenation in approximately $60 \%$ of subjects presenting with moderately severe or severe ARDS. Its efficacy was apparent regardless of the severity of impairment in baseline oxygenation or $\mathrm{C}_{\mathrm{RS}}$; subgroupings of ARDS based upon etiology, early versus late, or direct versus indirect injury; or type of aerosol delivery system used. Its effectiveness also appears to be higher in those with less severely impaired oxygenation and $\mathrm{C}_{\mathrm{RS}}$. This only suggests that the effectiveness of aerosolized prostaglandin $I_{2}$ is dependent upon FRC and therefore may be improved when used together with strategies that improve FRC (eg, prone positioning, recruitment maneuvers, and high PEEP).

\section{ACKNOWLEDGMENTS}

We acknowledge the diligence of our respiratory therapists, who are responsible for executing aerosolized prostaglandin $\mathrm{I}_{2}$ therapy and closely monitoring its effects. Without their dedication and high degree of professionalism, this study would not have been possible.

\section{REFERENCES}

1. Dantzker DR, Brook CJ, Dehart P, Lynch JP, Weg JG. Ventilationperfusion distributions in adult respiratory distress syndrome. Am Rev Respir Dis 1979;120(5):1039-1052.

2. Zapol WM, Snider MT. Pulmonary hypertension in severe acute respiratory failure. N Engl J Med 1977;296(9):476-480.

3. Gattinoni L, Presenti A, Torresin A, Baglioni S, Rivolta M, Rossi F, et al. Adult respiratory distress syndrome profiles by computed tomography. J Thorac Imaging 1986;1(3):25-30.

4. Bigatello LM, Hurford WE, Kacmarek RM, Roberts JD Jr, Zapol WM. Prolonged inhalation of low concentrations of nitric oxide in subjects with sever adult respiratory distress syndrome. Anesthesiology 1994;80(4):761-770.

5. Walmrath D, Schneider T, Pilch J, Grimminger F, Seeger W. Aerosolized prostacyclin in adult respiratory distress syndrome. Lancet 1993;342(8877):961-962.

6. Bein T, Metz C, Keyl C, Sendtner E, Pfeifer M. Cardiovascular and pulmonary effects of aerosolized prostacyclin administration in severe respiratory failure using a ventilator nebulization system. J Cardiovasc Pharmacol 1996;27(4):583-586

7. Putensen C, Hörmann C, Kleinsasser A, Putensen-Himmer G. Cardiopulmonary effects of aerosolized prostaglandin E1 and nitric oxide inhalation in subjects with acute respiratory distress syndrome. Am J Respir Crit Care Med 1998;157(6):1743-1747.

8. Jaffar Z, Ferrini ME, Buford MC, Fitzgerald GA, Roberts K. Prostaglandin I2-IP signaling blocks allergic pulmonary inflammation by preventing recruitment of $\mathrm{CD} 4+\mathrm{Th} 2$ cells into the airways in a mouse model of asthma. J Immunol 2007;179(9):6193-6203.

9. Vane JR, Anggård EE, Botting RM. Regulatory functions of the vascular endothelium. N Engl J Med 1990;323(1):27-36.

10. Ware LB, Matthay MA. The acute respiratory distress syndrome. N Engl J Med 2000;342(18):1334-1349.

11. Kallet RH, Katz JA. Respiratory system mechanics in acute respiratory distress syndrome. Respir Care Clin N Am 2003;9(3):297-319.

12. Kallet RH, Should PEEP titration be based on chest mechanics in patients with ARDS? Respir Care 2016;61(6):876-890.

13. Lang IM, Gaine SP. Recent advances in targeting the prostacyclin pathway in pulmonary arterial hypertension. Eur Respir Rev 2015; 24(138):630-641.

14. Manktelow C, Bigatello LM, Hess D, Hurford WE. Physiologic determinants of the response to inhaled nitric oxide in subjects with acute respiratory distress syndrome. Anesthesiology 1997;87(2):297-307.

15. Krafft P, Fridrich P, Fitzgerald RD, Koc D, Steltzer H. Effectiveness of nitric oxide inhalation in septic ARDS. Chest 1996;109(2):486-493.

16. Domenighetti G, Stricker H, Waldispuehl B. Nebulized prostacyclin (PGI2) in acute respiratory distress syndrome: impact of primary (pulmonary injury) and secondary (extrapulmonary injury) disease on gas exchange response. Crit Care Med 2001;29(1):57-62.

17. Bernard GR, Artigas A, Brigham KL, Carlet J, Falke C, Hudson L, Lamy L, et al. Report of the American-European consensus conference on acute respiratory distress syndrome: definitions mechanisms, relevant outcomes, and clinical trials coordination. Am J Respir Crit Care 1994;149(3):818-824.

18. ARDS Definition Taskforce, Ranieri VM, Rubenfeld GD, Thompson BT, Ferguson ND, Caldwell E, et al. Acute respiratory distress syndrome: the Berlin definition. JAMA 2012;307(23):2526-2533. 


\section{Aerosolized Prostacyclin Response in ARDS}

19. Knaus WA, Draper EA, Wagner DP, Zimmerman JE. Apache II: a severity of disease classification system. Crit Care Med 1985;13(10): 818-829.

20. Le Gall JR, Lemeshow S, Saulnier F. A new Simplified Acute Physiology Score (SAPS II) based on a European-North American multicenter study. JAMA 1993;270(24):2957-2963.

21. Murray JF, Matthay MA, Luce JM, Flick MR. An expanded definition of the adult respiratory distress syndrome. Am Rev Respir Dis 1988;138(3):720-723.

22. Acute Respiratory Distress Syndrome Network, Brower RG, Matthay MA, Morris A, Schoenfeld D, Thompson BT, Wheeler A. Ventilation with lower tidal volumes as a compared with traditional tidal volumes for acute respiratory distress syndrome. N Engl $\mathrm{J}$ Med 2000;342(18):1301-1308

23. Brower RG, Lanken PN, MacIntyre N, Matthay MA, Morris A, Ancukiewicz M, et al. Higher versus lower positive end-expiratory pressures in subjects with the acute respiratory distress syndrome. N Engl J Med 2004;351(4):327-336.

24. Siobal MS, Kallet RH, Pittet JF, Warnecke EL, Kraemer RW, Venkayya RV, Tang JF. Description and evaluation of a delivery system for aerosolized prostacyclin. Respir Care 2003;48(8):742-753.

25. Aerogen solo system instructions manual. Galway, Ireland: Aerogen Ltd; 2015:28.

26. Wexler HR, Lok P. A simple formula for adjusting arterial carbon dioxide tension. Can Anaesth Soc J 1981;28(4):370-372.

27. Walmrath D, Schneider T, Schermuly R, Olschewski H, Grimminger F, Seeger W. Direct comparison of inhaled nitric oxide and aerosolized prostacyclin in acute respiratory distress syndrome. Am J Respir Crit Care Med 1996;153(3):991-996.

28. Zwissler B, Kemming G, Habler O, Kleen M, Merkel M, Haller M, et al. Inhaled prostacyclin (PGI2) versus inhaled nitric oxide in adult respiratory distress syndrome. Am J Respir Crit Care Med 1996; 154(6): 1671-1677.

29. Pappert D, Busch T, Gerlach H, Lewandowski K, Radermacher P, Rossaint R. Aerosolized prostacyclin versus nitric oxide in children with severe acute respiratory distress syndrome. Anesthesiology 1995; 82(6):1507-1511.

30. van Heerden PV, Barden A, Michalopoulos N, Bulsara MK, Roberts BL. Dose-response to inhaled aerosolized prostacyclin for hypoxemia due to ARDS. Chest 2000;117(3):819-827.

31. Torbic H, Szumita PM, Anger KE, Nuccio P, LaGambina S, Weinhouse G. Inhaled epoprostenol vs. inhaled nitric oxide for refractory hypoxemia in critically ill patients. J Crit Care 2013;28(5):844-848.

32. Dunkley KA, Louzon PR, Lee J, Vu S. Efficacy, safety and medication errors associated with the use of inhaled epoprostenol for adults with acute respiratory distress syndrome: a pilot study. Ann Pharmacother 2013;47(6):790-796.

33. Falke KJ, Pontoppidan H, Kumar A, Leith DE, Geffin B, Laver MB. Ventilation with end-expiratory pressure in acute lung disease. J Clin Invest 1972;51(9):2315-2323.

34. Suter PM, Fairley B, Isenberg MD. Optimum end-expiratory airway pressure in patients with acute pulmonary failure. N Engl J Med 1975;292(6):284-289.

35. Kallet RH. A comprehensive review of prone positioning in acute respiratory distress syndrome. Respir Care 2015;60(11):1660-1687.
36. Boisramé-Helms J, Kremer H, Schini-Kerth V, Meziani F. Endothelial dysfunction in sepsis. Curr Vasc Pharmacol 2013;11(2):150-160.

37. Dicker RA, Morabito DJ, Pittet JF, Campbell AR, Mackersie RC. Acute respiratory distress syndrome criteria in trauma patients: why the definitions do not work. J Trauma 2004;57(3):522-526; discussion 526-528.

38. Kallet RH, Ho K, Gomez A, Lipnick M. Pulmonary dead space fraction differs according to etiology of acute respiratory distress syndrome. Respir Care 2016;61(10):OF-15:2527171.

39. Kallet RH, Jasmer RM, Pittet JF, Tang JF, Campbell AR, Dicker R, et al. Clinical implementation of the ARDS Network protocol is associated with reduced hospital mortality compared to historical controls. Crit Care Med 2005;33(5):925-929.

40. Rubenfeld GD, Caldwell E, Peabody E. Incidence and outcome of acute lung injury. N Engl J Med 2005;353(16):1685-1693.

41. Afshari A, Brok J, Moller AM, Wetterslev J. Aerosolized prostacyclin for acute lung injury (ALI) and acute respiratory distress syndrome (ARDS). Cochrane Database Syst Rev 2010;(8):CD007733.

42. Vieillard-Baron A, Charron C, Caille V, Belliard G, Page B, Jardin F. Prone positioning unloads the right ventricle in severe ARDS. Chest 2007;132(5):1440-1446.

43. Monchi M, Bellenfant F, Cariou A, Joly LM, Thebert D, Laurent I, et al. Early predictive factors of survival in the acute respiratory distress syndrome. Am J Respir Crit Care Med 1998;158(4):10761081

44. Squara P, Dhainaut JF, Artigas A, Carlet J, European Collaborative ARDS Working Group. Hemodynamic profile in severe ARDS: results of the European Collaborative ARDS study. Intensive Care Med 1998;24(10):1018-1028.

45. Kallet RH, Matthay MA. Hyperoxic acute lung injury. Respir Care 2013;58(1):123-141

46. Terragni PP, Rosboch G, Tealdi A, Corno E, Menaldo E, Davini O, et al. Tidal hyperinflation during low tidal volume ventilation in acute respiratory distress syndrome. Am J Respir Crit Care Med 2007;175(2):160-166.

47. Bellani G, Laffey JG, Pham T, Fan E, Brochard L, Esteban A, et al. Epidemiology, patterns of care and mortality for patients with acute respiratory distress syndrome in intensive care units in 50 countries. JAMA 2016;315(8):788-800.

48. Briel M, Meade M, Mercat A, Brower RG, Talmor D, Walter SD, et al. Higher vs lower positive end-expiratory pressure in patients with acute lung injury and acute respiratory distress syndrome. JAMA 2010;303(9):865-873.

49. Sud S, Friedrich JO, Taccone P, Polli F, Adhikari NKJ, Latini R, et al. Prone ventilation reduces mortality in patients with acute respiratory failure and severe hypoxemia: systematic review and metaanalysis. Intensive Care Med 2010;36(4):585-599.

50. Suzumura EA, Figueiró M, Normilio-Silva K, Laranjeira L, Oliveira $\mathrm{C}$, Buehler AM, et al. Effect of alveolar recruitment maneuvers on clinical outcomes in patients with acute respiratory distress syndrome: a systematic review and meta-analysis. Intensive Care Med 2014;40(9):1227-1240.

51. Alhazzani W, Alshahrani M, Jaeschke R, Forel JM, Papazian L, Sevransky J, Meade MO. Neuromuscular blocking agents in acute respiratory distress syndrome: a systematic review and meta-analysis of randomized controlled trials. Crit Care 2013;17(2):R43.

This article is approved for Continuing Respiratory Care Education credit. For information and to obtain your CRCE

(free to AARC members) visit www.rcjournal.com

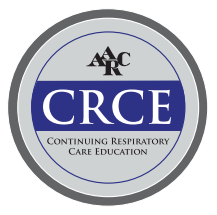

